\title{
Editorial
}

\section{The contribution of Robert William Kerwin (1955-2007) to Psychiatry in Brazil}

\section{A contribuição de Robert William Kerwin (1955-2007) para a Psiquiatria brasilleira}

Recently, the world scientific community and particularly our Revista Brasileira de Psiquiatria (Brazilian Journal of Psychiatry) had a great loss: Professor Robert W. Kerwin, from Great Britain. Robert Kerwin's career was full of singularities and brilliance.

In 1979, he started his studies toward a PhD degree at the University of Bristol. Two years later, at the early age of 25, he completed several pharmacological studies in animals investigating the action of different neurotransmitters in the brain. These studies generated more than a dozen articles published in specialized periodicals between 1979 and 1981, including a highly cited publication in Nature. ${ }^{1}$ This paper, on the biochemical characterization of the newly discovered frontal cortical dopamine systems, was of critical importance to the understanding of dopaminergic mechanisms involved in psychosis and other psychiatric conditions. Rob (as he preferred to be called) later pursued the conclusion of his medical education and, by 1988, he completed his training in Psychiatry at the Maudsley Hospital in London. Only two years later, he was appointed Senior Lecturer jointly in Psychiatry and Neuroscience at the Institute of Psychiatry (IoP) of the University of London, and Consultant Psychiatrist at the Maudsley Hospital.

At the loP, he pioneered the use of both post mortem molecular approaches working with Prof. Ian Everall, and in vivo functional imaging techniques to the study of glutamatergic, GABAergic and dopaminergic hypotheses of schizophrenia. At the same time, he mentored the IoP team that, under the leadership of Prof Lyn S. Pilowsky, implemented in vivo receptor imaging studies investigating the brain receptors occupancy by all antipsychotic agents. ${ }^{2} \mathrm{He}$ also established in Great Britain the application of pharmacogenetic studies to the investigation of the relationship between neurotransmitter genes and the response to psychopharmacological agents, ${ }^{3}$ together with Dr. Maria Arranz and Dr. David Collier.

In 1996, he was appointed Professor of Clinical Neuropharmacology at the loP, and Head of the Department of Clinical Pharmacology of King's College School of Medicine and Dentistry, being the youngest psychiatrist ever to reach those positions. He raised huge amounts of funds from research agencies to finance his studies and staff, and published many dozens of research articles that have been cited with great regularity in the scientific literature on his fields of interest. Tributes to the significance of his scientific contributions are currently being paid internationally. ${ }^{4}$

The invitation for Rob Kerwin to become a member of RBP's international editorial board came in 1999, in recognition to his important influence on the start up of Neuroscience research applied to Psychiatry in Brazil.

Rob first visited Brazil in 1990, invited by the Institute of Psychiatry of the Medical School of the Universidade de São Paulo (IPQ-HCFMUSP). During his stay, he taught a course on the neurochemistry of schizophrenia, gave several lectures, and discussed different projects and research ideas with local 
mental health professionals. Rob's eclectic teachings on post mortem, functional neuroimaging and molecular genetics had a profound impact on our community, demonstrating the importance of contemporary neuroscientific techniques and their use in Psychiatry. Rob returned to São Paulo in 1994, when he lectured during a schizophrenia symposium organized by local psychiatrists.

As a consequence of those visits, the two authors of this text went to London during the 1990's and spent many years working under Rob Kerwin's supervision at the loP. After benefiting from his guidance and support, we both came back to Brazil with all the enthusiasm for Neuroscience research that Rob had inoculated in us. This led to the setting up of the first psychiatric neuroimaging research group at the IPQ-HCFMUSP, in association with the Institute of Radiology (InRad) of the Universidade de São Paulo. Also, the liaison with Rob's group paved the way for our colleague Rodrigo A. Bressan to establish an in vivo neurochemical imaging section at the Universidade Federal de São Paulo (UNIFESP), after spending a number of years working in this field at the loP in London.

We brought Rob back to São Paulo to take part in the first large international conference on Neuroscience applied to Psychiatry to be organized in Brazil, in 1998, when his lectures were attended by more than 400 people. Finally, during his last visit to Sao Paulo in April 2002, Rob gave the opening lecture of the festivities for the $50^{\text {th }}$ anniversary of the IPQ-HCFMUSP, celebrated during the entire length of that year.

Rob Kerwin was, undoubtedly, one of the greatest neuroscientists in the transition between the $20^{\text {th }}$ and $21^{\text {st }}$ centuries. In Brazil, he will be remembered not only by his personal scientific contributions, but also by the brightness and patience with which he helped us to realize the relevance of Neuroscience to our medical specialty. He was a proper teacher never afraid to generously transmit his knowledge and to encourage us to make our own contributions to the worldwide knowledge in this field. He had a sharp understanding of the problems he wanted to focus on, and was always looking for the precise question to start a new research project; "try to keep it simple", he always used to say.

Rob had a number of other interests in life. He particularly enjoyed flying, and was a very good pilot. He was also a great father of three beautiful girls.

Geraldo Busatto Filho, Valeria Bigliani Ferreira Department of Psychiatry, Medical School, Universidade de São Paulo (USP), São Paulo (SP), Brazil
Financing: None

Conflict of interests: None

\section{References}

1. Pycock CJ, Kerwin RW, Carter CJ. Effect of lesion of cortical dopamine terminals on subcortical dopamine receptors in rats. Nature. 1980;286(5768):74-6.

2. Pilowsky LS, Costa DC, Ell PJ, Murray RM, Verhoeff NP, Kerwin RW. Clozapine, single photon emission tomography, and the D2 dopamine receptor blockade hypothesis of schizophrenia. Lancet. 1992;340(8813): 199-202.

3. Kerwin RW. A perspective on progress in pharmacogenomics. Am J Pharmacogenomics. 2003;3(6):371-3.

4. Taylor D. Professor Robert W. Kerwin, MA, PhD, MB BChir, DSc, FRCPsych: 1955-2007. CNS Drugs. 2007;21(4):265. 